\title{
Adapter Molecule crk
}

National Cancer Institute

\section{Source}

National Cancer Institute. Adapter Molecule crk. NCI Thesaurus. Code C17414.

Adapter molecule crk (304 aa, $34 \mathrm{kDa}$ ) is encoded by the human CRK gene. This protein is involved in the modulation of signal transduction. 